\title{
STRATEGI PEMASARAN HOME INDUSTRY TEMPE DALAM MENINGKATKAN KESEJAHTERAAN EKONOMI DI KAMPUNG PULO
}

\author{
GUNARTIN $^{1}$ \\ FATMAWATI PUTRI ${ }^{2}$ \\ ${ }^{1}$ Dosen Program Studi Pendidikan Ekonomi Universitas Pamulang \\ ${ }^{2}$ Mahasiswa Program Studi Pendidikan Ekonomi Universitas Pamulang \\ ${ }^{*}$ email: atin_gunartin@yahoo.com ${ }^{1}$
}

\begin{abstract}
ABSTRAK
Tujuan dari penelitian ini adalah untuk mendeskripsikan strategi pemasaran yang dilakukan oleh para home industry tempe di Kampung Pulo Tangerang Selatan dalam upaya meningkatkan kesejahteraan ekonomi, di era persaingan yang kompetitif dengan banyaknya pilihan makanan yang ditawarkan oleh produsen. Peneliti memilih pendekatan metode kualitatif deskriptif pada penelitian ini dengan fokus pada eksploitasi fenomena dan mendeskripsikan strategi memasarkan produk tempe sehingga bisa bertahan di era persaingan yang kompetisi. RT 04 RW 20 Kampung Pulo Kecamatan Kedawung merupakan lokasi penelitian home industry tempe, dengan pertimbangan merupakan sentral pengrajin tempe di Tangerang Selatan dan menjadi unik karena sebagian besar warga Kampung Pulo adalah pengrajin tempe. Data yang dikumpulkan bersifat primer melalui obeservasi dan wawancara langsung terhadap informan agar diperoleh data yang diperlukan serta data skunder yang bersumber dari artikel, jurnal dan situs di internat terkait dengan topik penelitian. Adapun teknik pengumupulan data melalui obserwasi, dokumentasi dan wawancara mendalam guna memperoleh data yang akurat, serta dianalisa secara keseluruhan atau menjelaskan tahap akhir untuk dideskripsikan, sehingga disebut teknik analisis deskriptif. Hasil penelitian dapat dideskripsikan bahwa dalam memasarkan produknya warga pengrajin tempe Kampung tempe melalui strategi: 1) pemilihan bahan baku untuk menghasilkan tempe yang berkualitas; 2) harga yang bersaing; 3) bentuk dan ukuran yang disesuaikan; 5) kemasan yang menarik; 6) cara mendistribusikan dan 7) menjaga keharmonisan sesama pengrajin. Hal ini dilakukan untuk mencapai omset penjualan maksimal dengan demikian dapat meningkatkan kesejahteraan ekonomi.
\end{abstract}

Kata Kunci: Strategi Pemasaran, Home Industri, Kesejahteraan Ekonomi 


\section{PENDAHULUAN}

Indikator tingkat pertumbuhan ekonomi suatu negara dapat ditunjukan dengan pertumbuhan ekonomi itu sendiri. Artinya, peningkatan output yang dihasilkan merupakan sebab banyaknya faktor produksi yang dimanfaatkan dalam proses produksi. Indikator pertumbuhan ekonomi tidak sekedar mengukur tingkat pertumbuhan output, namun juga memberikan indikasi sebesar apa kegiatan ekonomi dalam satu periode, menghasilkan pendapatan yang merupakan tolak ukur kesejahteraan bagi masyarakat. (Schumpeter dalam Adi Raharjo, 2012). Tingkat pertumbuhan ekonomi sebagai tolak ukur tingkat kesejahteraan ekonomi. Deskripsi tingkat pertumbuhan ekonomi Indonesia tiga tahun terakhir (tahun 2015-2017) mengalami peningkatan meskipun tidak signifikan disajikan pada Tabel 1.

Tabel 1 Pertumbuhan Ekonomi Indonesia Tahun 2017.

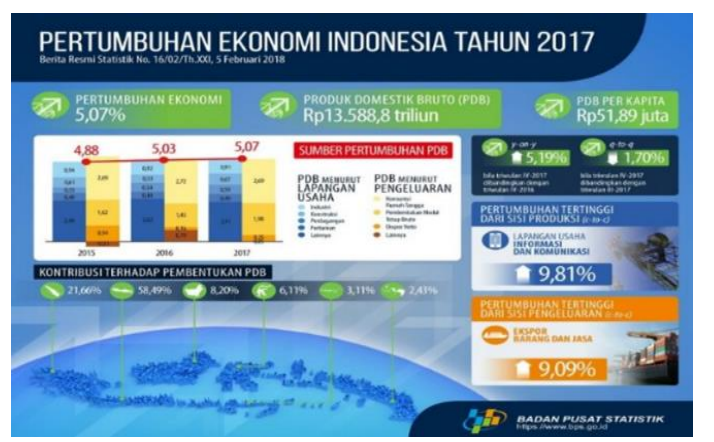

Peningkatan pertumbuhan ekonomi seyogyanya diikuti oleh tingkat kesejahteraan ekonomi masyarakat. Kesejahteraan ekonomi menjadi hak setiap warga, oleh karenanya setiap warga mempunyai hak dan peluang yang sama untuk mengembangkan potensi sumberdaya ekonomi yang dimiliki. Artinya, untuk dapat mencapai tingkat kesejahteraan ekonomi yang layak setiap warga harus berusaha dan bekerja keras untuk dapat mewujudkannya, baik sebagai pekerja disuatu instansi/organisasi ataupun sebagai wirausaha, yang tentunya harus disesuaikan dengan kemampuan dan potensi diri.

Menjadi wirausaha memang bukan hal yang mudah, karena untuk menjadi seorang wirausaha banyak motif yang melmjadi atarbelakangnya, seperti: 1) memang berlatar belakang wirausaha; 2) menjadi wirausaha karena meneruskan usaha orangtua; 3) menjadi wirausaha karena terinspirasi kesuksesan wirausaha lain; serta 4) menjadi wirausaha karena tidak satu organisasipun menerima sebagai pekerja sehingga terpaksa menjadi wirausaha. Apapun motivasinya, wirausaha merupakan kegiatan proses 
produksi (industri) yang memfaatkan faktor produksi untuk menghasilkan barang dan jasa (Purwo, 2000). Secara garis besar industri dapat diklasifikasikan seperti yang disajikan pada Tabel 2.

Tabel 2. Klasifikasi Industri

\begin{tabular}{|c|l|l|l|}
\hline No & $\begin{array}{c}\text { Jenis } \\
\text { Industri }\end{array}$ & \multicolumn{1}{|c|}{ Kapasitas } & $\begin{array}{c}\text { Asset dan } \\
\text { Modal }\end{array}$ \\
\hline 1 & $\begin{array}{l}\text { home } \\
\text { Industry }\end{array}$ & 1-4 orang & $\begin{array}{l}\text { Tidak } \\
\text { ditentukan }\end{array}$ \\
\hline 2 & $\begin{array}{l}\text { Industri } \\
\text { Kecil }\end{array}$ & 5-19 orang & Rp 50 juta \\
\hline 3 & $\begin{array}{l}\text { Indusri } \\
\text { Sedang }\end{array}$ & 20-99 orang & $\begin{array}{l}\text { Rp 50-500 } \\
\text { Juta }\end{array}$ \\
\hline 4 & $\begin{array}{l}\text { Industri } \\
\text { Besar }\end{array}$ & $\begin{array}{l}\text { 100 orang } \\
\text { atau lebih }\end{array}$ & $\begin{array}{l}\text { Rp 500 Juta- } \\
100 \text { Miliyar }\end{array}$ \\
\hline
\end{tabular}

Sumber: Undang-undang No. 20 tahun 2008

Berdasarkan Tabel 2, yang paling sederhana adalah adalah tingkat home industry, artinya paling memungkinkan untuk dilakukan masyarakat luas karena selain kebutuhan modalnya, tenaga kerja yang dibutuhkan juga sedikit. home industry merupakan kegiatan produksi yang dilakukan dirumah sehingga belum perlu biaya sewa ruang untuk melakukan kegiatan produksi. Dengan demikian biaya yang dibebankan tidak terlalu besar. Memang home industry ditinjau dari skala produksinya masih relatif keci namun dari yang kecil-kecil ini jika diakumulasikan akan menjadi besar, dan sudah terbukti bahwa usaha mikro kecil telah menyelamatkan perekonomian bangsa Indonesia dari krisis.

Home industry selain lebih mudah dilakukan terkait dengan penyediaan modal, juga memiliki manfaat yang sangat besar dalam kontribusinya pada perekonomian, antara lain: 1) menyediakan lapangan kerja bagi masyarakat yang bekerja paruh waktu; 2) sumber tambahan penghasilan; dan 3) menyediakan kebutuhan masyarakat setempat. Besarnya peran home industry pada peningkatan kesejahteraan ekonomi, penting bagi masyarakat mendukung penuh kegiatan ekonomi kecil tersebut. Menurut Miyasto (2013) menyatakan bahwa industri dan perdagangan mendominasi aktivitas ekonomi masyarakat karena merupakan aset potensial penggerak ekonomi kerakyatan.

Kesejahteraan ekonomi menjadi motivasi bagi setiap individu untuk terus berusaha dan berkarya menghasilkan manfaat bagi orang lain. Salah satu wujud kegiatan meningkatkan kesejahteraan ekonomi 
sudah ditunjukkan oleh masyarakat RT. 04 RW.20 Kampung Pulo Kelurahan Kedaung Pamulang Tangerang Selatan. Kampung Pulo merupakan kampung yang masyarakatnya sebagian besar adalah pengrajin tempe. Dari kegiatan home industry sebagai pengrajin tempe ini masyarakat Kampung Pulo menggantungkan hidupnya dari tahun ke tahun. Artinya, sumber penghasilan untuk memenuhi kebutuhan sehari hari yaitu sebagai pengrajin tempe. Tempe merupakan salah satu jenis makanan yang berbahan baku kedelai.

Seiring berkembangnya teknologi dan pergeseran pola konsumsi masyarakat yang dihadapkan pada banyaknya pilihan makanan tentu merupakan tantangan tersendiri bagi pengrajin tempe untuk terus bertahan ditengah-tengah persaingan yang semakin ketat. Untuk terus eksis agar kesejahteraan ekonominya terpenuhi tentu membutuhkan strategi khusus untuk memasarkan hasil produksi tempenya agar tetap mendapatkan tempat dihati masyarakat. Berdasarkan paparan kondisi di atas, membuat ketertarikan peneliti atas fenomena yang terjadi di masyarakat Kampung Pulo untuk mengembangkan usaha home industry nya di era maraknya makanan cepat saji (fast food) dengan mengangkat tema "Strategi Pemasaran Home Industry Tempe Dalam Meningkatkan Kesejahteraan Ekonomi Di Kampung Pulo"

\section{Fokus Penelitian}

Home industri Tempe di Kampung Pulo merupakan kegiatan industri rumahan yang sudah berlangsung bertahun-tahun, bahkan bisa dibilang ada beberapa home industry tempe yang merupakan industri keluarga secara turun-temurun. Tentu hal ini tidak mudah dilakukan untuk bisa bertahan karena di Kampung Pulo sendiri pengrajin tempe terus bertambah dari waktu ke waktu, belum lagi maraknya penawaran variasi pilihan makanan selain tempe. Berdasarkan kondisi tersebut penelitian ini difokuskan pada bagaimana cara pengrajin tempe mampu bertahan dan meningkatkan kesejahteraan ekonomi.

\section{Tujuan Penelitian}

Mengacu pada fokus penelitian di atas, tujuan dari penelitian ini adalah untuk mendeskripsikan strategi pemasaran yang dilakukan oleh para home industry tempe di Kampung Pulo 
dalam upaya meningkatkan kesejahteraan ekonomi.

\section{METODOLOGI PENELITIAN}

Peneliti melakukan observasi dan wawancara untuk pengumpulan data baik yang bersifat primer maupun skunder. Dengan penggalian informasi yang mendalam dari informan kunci, dalam penelitian ini kehadiran peneliti berlaku sebagai instrumen penelitian (Sugiyono, 2011). Atas fenomena yang terjadi di Kampung Pulo yang mampu meningkatkan kesejahteraan masyarakat dengan home industry tempe, peneliti tertarik untuk mendeskripsikan strategi pemasaran yang dilakukan sehingga pengrajin tempe mampu bertahan bahkan berkembang di era persaingan bisnis yang sangat kompetitif. Untuk itu peneliti selaku instrumen penelitian melakukan sendiri penggalian informasi dengan cara wawancara baik secara terstruktur maupun tidak terstruktur.

Informasi yang diperoleh atau dikumpulkan bersumber dari informan sebagai narasumber melalui wawancara, observasi atau memberikan keterangan, pendapat, pemikiran dan persepsinya. (Sukmadinata, 2006). Untuk memetakan jumlah sampel pada penelitian dilakukan dengan purposive sampling, yaitu pengambilan sampel didasarkan atas pertimbangan yang paham atas obyek penelitian sehingga informasi yang diperoleh dapat dipertanggungjawabkan (Sugiyono, 2012). Mengacu pada pernyataan tersebut, pada penelitian ini informan adalah pengrajin home industri tempe, ketua RT, pekerja dan konsumen.

Peneliti memilih pendekatan metode kualitatif deskriptif pada penelitian dengan memfokuskan pada eksploitasi fenomena dan mendeskripsikan cara atau strategi dalam memasarkan produk tempe sehingga bisa bertahan ditengah-tengah kompetisi yang semakin ketat. RT. 04 RW. 20 Kampung Pulo Kecamatan Kedawung Tangerang Selatan merupakan lokasi penelitian home industry tempe, dengan pertimbangan merupakan sentral pengrajin tempe di Tangerang Selatan dan menjadi unik karena sebagian besar warga Kampung Pulo adalah pengrajin tempe.

Data yang dikumpulkan bersifat primer melalui obeservasi dan wawancara langsung terhadap informan agar diperoleh data yang diperlukan (Sukandar, 2006). Selain data primer, 
pada penelitan ini juga didukung data skunder yang bersumber dari artikel, jurnal dan situs di internat terkait dengan topik penelitian. Adapun teknik pengumupulan data melalui obserwasi, dokumentasi dan wawancara mendalam guna memperoleh data yang akurat, serta dianalisa secara keseluruhan atau menjelaskan tahap akhir untuk dideskripsikan, sehingga disebut teknik analisis deskriptif.

\section{HASIL PENELITIAN}

\section{Profil Home Industry tempe}

\section{Kampung Pulo.}

Kampung Pulo merupakan wilayah kelurahan Kedaung Pamulang Selatan yang terdiri dari 20 Rukun Warga (RW) dan 97 Rukun Tetangga (RT) dan berbatasan wilayah sebelah utara dengan kelurahan Kp. Sawah, sebelah selatan dan timur berbatasan dengan kelurahan Ciputan sebentara sebelah barat berbatasan dengan kelurahan Bambu Apus. Luas area yang dimiliki kelurahan Kedawung 276,70 Ha dengan jumlah penduduk 39.172. (sumber: data kelurahan) dengan beragai tingkat usia. Home industry tempe Kapung Pulo ini unik, karena dari hasil obserwasi dan wawancara, justru home industry tempe bukan asli suku Betawi melainkan para pendatang yang merintis usaha dan memiliki lahan milik suku Betawi karena dijual kepada para pendatang. Keadaan ini terus berlangsung seiring perkembangan waktu, keberhasilan para pendatang ini mengundang pendatang yang lain untuk mengadu nasib di bidang yang sama yaitu pengrajin tempe. Tentu saja keberhasilan itu harus melalui proses yang panjang, tidak serta merta sukses. Hal inilah yang membuat ketertarikan peneliti bahwa suatu usaha itu dapat berjalan dan berkembang karena banyak faktor, salah satunya karena suatu produk/barang itu laku dipasaran. Sedangkan untuk laku dipasaran membutuhkan strategi agar suatu barang itu tetap diminati oleh konsumen dan dapat terus dikembangkan sehingga tujuan untuk meningkatkan kesejahteraan ekonomi dapat terwujud.

\section{Strategi Pemasaran}

Home industry tempe di Kampung Pulo secara perlahan tapi pasti mengalami perkembangan yang baik. Hal ini dapat ditunjukkan dengan terus bertambahnya pelaku home industry tempe yang semakin banyak dan 
menjadi sumber peenghasilan guna meningkatkan kesejahteraan ekonomi. Dengan bertambahnya home industry tempe di satu wilayah yaitu Kampung Pulo tentu membutuhkan kiat khusus untuk bisa bertahan dengan usahanya, artinya persaingan semakin ketat. Banyak faktor yang membuat suatu usaha itu terus eksis, diantaranya: cara mengelola usaha (memanajemen), menjaga kualitas produk, harga, lokasi dan bagaimana cara mengkomunikasikan produk tersebut pada konsumen agar suatu produk dapat sampai ke konsumen.

Pada penelitian ini difokuskan pada penggalian informasi dan mendeskripsikan bagaimana cara pengrajin tempe tersebut memasarkan tempenya dengan pertimbangan: 1) banyak pelaku home industry yang sebagian dari mereka adalah saudara, dalam satu wilayah sama-sama memproduksi tempe; 2) semakin banyak pilihan makanan; 3) bagi anak jaman sekarang sudah ganti pola konsumsi yaitu mereka lebih berselera makan makanan cepat saji seperti sosis, nuget, tempura, fried chiken bukan jamannya lagi mengkonsumsi tahu dan tempe. Hal ini merupakan tantangan bagi pengrajin tempe untuk mampu menyikapi perubahan dan terus meningkatkan kesejahteraan ekonomi.

Berdasarkan hasil analisa penelitian, home industry tempe $\mathrm{di}$ Kampung Pulo ini mempunyai karakter sendiri untuk terus bertahan dan berkembang, yaitu dengan strategi pemasaran meskipun masih tergolong sederhana dan tradisional, yaitu:

\section{a. Pemilihan Bahan Baku Utama}

Bahan baku merupakan faktor produksi utama yang menentukan hasil, artinya suatu produk terlebih produk makanan faktor bahan baku sangat menentukan kualitas hasil produksi. Kualitas bahan baku yang baik akan menghasilkan barang jadi yang baik pula, selain cara mengolahnya. Kedelai merupakan bahan baku pembuatan tempe, tentu saja kedelai yang baik akan menghasilkan tempe yang baik pula. Hasil observasi dan wawancara ditemukan bahwa home industry tempe Kampung Pulo menggunakan tiga jenis kualitas kedelai dengan katagori kualitas kedelai super, baik dan sedang. Memang tempe yang dihasilkan tidak sama dan masing- 
masing mempunyai pangsa pasar tersendiri.

\section{b. Harga}

Harga sangat berpengaruh pada permintaan barang dalam hal ini adalah tempe. Tentunya bahan baku kedelai super lebih mahal dari yang berkualitas sedang, artinya biaya produksinya lebih tinggi dan hal ini akan menentukan harga jual tempe. Menurut Sukirno (2014) dikatakan besarnya output (hasil produksi) sebanding dengan input (biaya faktor produksi) dan akan menentukan harga jual. Dari hasil penelitian, para pengrajin tempe Kampung Pulo sudah memiliki pangsa pasar sendiri sesuai selera atas kualitas tempe yang dihasilkan dan berbeda beda sesuai dengan bahan bakunya.

\section{c. Bentuk dan Ukuran}

Bentuk dan ukuran mempunyai daya tarik tersendiri di hati konsumen. Dari hasil observasi ada beberapa bentuk dan ukuran tempe yang diproduksi dan hal ini menupakan salah satu ciri dari masing-maisng home industry tempe Kampung Pulo, yaitu ada yang silinder, pipih, dan kotak dengan berbagai ukuran besar, sedang dan kecil. Bahkan cara motong tempe pun menjadi ciri tersendiri, ada yang potongan kotak dan seromg.

\section{d. Kemasan}

Kemasan (packing) merupakan salah satu strategi pemasaran. Ketertarikan konsumen terkadang bukan dari rasa tempe melainkan kemasannya. Dari hasil penelitian di home industry tempe Kampung Pulo ada yang dikemas dengan daun dan plastik. Tentu ini menjadi salah satu strategi memasarkan bahwa ada konsumen yang memilih tempe kemaan daun karena lebih alami dan heginis, sementara yang lain lebih suka memilih kemaan plastik karena transparan sehingga terlihat dari luar akan kondisi tempe baru atau tempe kemarian.

\section{e. Cara mendistribusikan}

Distribusi merupakan salah satu kegiatan ekonomi memindahkan suatu produk dari tangan produsen ke tangan konsumen. Dari hasil observasi dan wawancara, pendistribusian tempe di home industry tempe Kampung Pulo ada yang dikelilingkan, di titipkan ke warung-warung sayur, di jual sendiri di pasar, dan ada yang dipasok ke 
home industry kripik tempe ataupun dipasok di pasar moderen. Semua ini mereka lakukan supaya tempe habis pada hari itu juga karena tempe bukan bahan makanan yang tahan lama.

\section{f. Menjaga Keharmonisan Sesama Pengrajin Tempe}

Karena satu kampung mayoritas pengrajin tempe, tentu bukan hal mudah bersaing dengan tetangga sendiri bahkan keluarga sendiri. Dari hasil analisa ternyata untuk menjaga keharmonisan hidup bermasyarakat serta meningkatkan kesejahteraan ekonomi mereka sudah mempunyai komitmen yang terbangun di Kampung Pulo bahwa mereka tidak akan merebut lahan pesaingnya, artinya masing-masing home industry tempe Kampung Pulo sudah berkomitmen yang sudah menjadi pasarnya pengrajin lain maka tidak akan pernah direbut atau dimasuki pengrajin satunya.

\section{KESIMPULAN}

Berdasarkan hasi temuan dan analisa penelitian, dapat peneliti simpulkan penting untuk bersaing secara sehat dalam meningkatkan kesejahteraan ekonomi. Dengan tetap menjaga keharmonisan dan sinergisitas antar home industry tempe Kampung Pulo justru akan memudahkan mereka untuk tetap eksis mengembangkan usahanya. Tentu hal ini juga tidak lepas dari strategi pemasaran yang didasarkan atas:

a. Pemilihan bahan baku yang baik akah menghasilkan produk yang berkualitas;

b. Harga yang bersaing sehingga dapat dijangka oleh masyarakat;

c. Bentuk dan ukuran yang disesuaikan kebutuhan;

d. Kemasan yang menarik;

e. Cara mendistribusikan untuk sampai ke tangan konsumen

f. Menjaga keharmonisan sesama pengrajin tempe agar terjalin kerjasama dan kerukunan bermasyarakat

\section{SARAN}

Berdasarkan hasil penelitian, yang bisa peneliti sarankan dalam upaya meningkatkan kesejahteraan ekonomi melalui strategi pemasaran biar tetap eksis yaitu:

a. Bahan baku merupakan modal dasar kualitas hasil produksi, jadi saran 
peneliti harus tetap memilih bahan baku yang baik untuk menghasilkan kualitas yang baik pula dan terstandar sehingga omset penjualan bisa tercapai

b. Harga sebernanya relatif, artinya kualitas yang baik akan berdampak pada harga yang relatif mahal wajar karena bahan baku yang baik berdampak pada biaya produksi. Artinya, harga yang wajar sesuai dengan harga pasar tentu akan lebih aman dari pada mengejar keuntungan tinggi tetapi ditinggalkan konsumen karena mahal.

c. Kemasan yang menarik tetap akan menjadi daya tarik tersendiri bagi konsumen, jadi saran peneliti tetap melakukan surve untuk mengetahui selera konsumen.

d. Menjemput bola istilahnya akan lebih baik dari menunggu bola, pepatah dari pendistribusian suatu produk. Jadi tidak menunggu konsumen tetapi kitalah yang harus mengantarkan ke konsumen.

e. Dalam berbisnis bersaing itu wajar sejauh persaingan yang sehat, jadikan pensaing itu adalah mitra bisnis kita.

\section{DAFTAR PUSTAKA}

Adi. Raharjo, 2006. Pengantar Kesejahteraan Sosial. Bandung: Refika Aditama.

Badan Pusat Statistik Indonesia. 2017. Pertumbuhan Ekonomi Tahun 2017.

Fatmawati, Nurul Laela. 2009. Strategi Pengembangan Industri Kecil Tempe Di Kecamatan Pedan Kabupaten Klaten.

Miyasto 2013. Pengaruh Desentralisasi Fiskal Terhadap Pertumbuhan Ekonomi Daerah dan Ketimpangan Pendapatan (studi kasus Kabupaten/Kota di Jawa Tengah). Diponegoro Journal Economics Vol.2 Nomor 1, Juni 2011

Purwo Minto, 2000. Analisis Pengaruh Bahan Baku untuk Menghasilkan Barang dan Jasa. Universitas Diponegoro Semarang

Schumpeter dalam Adi Raharjo, 2006. Pengaruh Pengeluaran Pemerintah, Investasi Swasta dan Angkatan Kerja Terhadap Pertumbuhan Ekonomi

Sugiyono, 2012. Metode Penelitian Kuantitatid dan Kualitatif. Rajawali Pers Jakarta

Sugiyono. 2011. Metode Penelitian Kuantitatif Kualitatif dan $R \& D$. Bandung: Alfabeta.

Sukandar. 2012. Metodologi Penelitian: Petunjuk Praktis Untuk Peneliti Pemula. Yogyakarta: Universitas Gadjahmada Press. 
Sukirno Sadono, 2014. Pengantar Ekonomi Mikro. Jakarta: Raja Perindo Persada
Sukmadinata, 2006, Metode Penelitian Pendidikan. Raja Grafindo Persada Jakarta. 